\title{
Improving the Heat Transfer Rate for Multi Cylinder Engine Piston and Piston Rings
}

\author{
Ravi Manohar ${ }^{1}$, V.Mahanandi Reddy ${ }^{2}$ \\ ${ }^{I}$ (Mechanical Engineerig, G.Pulla Reddy Engineerig College (Autonomous) /J Ntu Anantapur , India) \\ ${ }_{2}^{2}$ (Mechanical Engineerig, G.Pulla Reddy Engineerig College (Autonomous) /J Ntu Anantapur , India )
}

\begin{abstract}
The four stroke otto engine uses just one of the four strokes to perform work. This causes various problems: The engine runs jerkily, and this can only be prevented by a large flywheel, which needs a lot of space and weights pretty much in addition. In this thesis, thermal loads and pressures produced in the multi cylinder petrol engine Toyota 86 Car by varying compression ratios 14:1, 15:1, 18:1, 20:1 and 25:1 are calculated by mathematical correlations And also calculating the effect of these thermal loads on piston and piston rings by varying materials Cast Iron, Aluminum Alloy 6061 for piston and Cast Iron and Steel for piston rings.FEA transient thermal analysis is performed on the parametric model to validate the effect of thermal loads on piston and piston rings for different materials. The optimum value of compression ratio and the better material is determined by analysis results to improve the heat transfer rate of multi cylinder engine piston and piston rings. Dynamic analysis is done on the piston by applying the pressures developed and also static analysis by applying the maximum pressure.
\end{abstract}

Keywords: Multi cylinder engines, Piston, Piston rings, Compression ratio, Materials, FEA analysis

\section{Introduction}

A piston is a component of reciprocating engines, reciprocating pumps, gas compressors and pneumatic cylinders, among other similar mechanisms. It is the moving component that is contained by a cylinder and is made gas-tight by piston rings. In an engine, its purpose is to transfer force from expanding gas in the cylinder to the crankshaft via a piston rod and/or connecting rod. In a pump, the function is reversed and force is transferred from the crankshaft to the piston for the purpose of compressing or ejecting the fluid in the cylinder.

In some engines, the piston also acts as a valve by covering and uncovering ports in the cylinder wall. A piston ring is a split ring that fits into a groove on the outer diameter of a piston in a reciprocating engine such as an internal combustion engine or steam engine.

\section{Compression Ratio}

The compression ratio of an internal-combustion engine or external combustion engine is a value that represents the ratio of the volume of its combustion chamber from its largest capacity to its smallest capacity. In a piston engine it is the ratio between the volume of the cylinder and combustion chamber when the piston is at the bottom of its stroke, and the volume of the combustion chamber when the piston is at the top of its stroke.

\subsection{Effect Of Compression Ratio On Engine Performance}

In an internal combustion engine, a piston compresses a large volume of a mixture of fuel and air into a very small space. The ratio of the maximum piston volume to the minimum compressed volume is called the compression ratio. Compressing the fuel and air will make them burn faster, which (though I'm not sure directly how) makes the engine run better. There are secondary benefits to high compression ratios, too. High compression ratio engines burn both much more cleanly and much more efficiently than lower-compression engines. The increase in efficiency is due to the additional heat and Brownian motion caused by compression fully vaporizing the fuel, considering how much work is put into cooling the fuel-air mix in turbocharged cars. Another issue is engine efficiency as a function of RPMs. An engine limits power by reducing the intake of fuel and air to an engine; if only half the fuel and air is entering a piston, the compression ratio is effectively halved as well.

\subsection{Specifications Of Toyota 86 Engine Type}

4-Stroke multi cylinder petrol engine, Cylinder bore $=86 \mathrm{mmStroke}$ length $=86 \mathrm{~mm}$

Speed $=2000 \mathrm{rpm} \quad$ Fuel consumption $=0.25 \mathrm{~kg} / \mathrm{BP} / \mathrm{hr}$

Higher calorific value of fuel $=47000 \mathrm{kj} / \mathrm{kg}, \quad$ Maximum gas pressure $=5 \mathrm{~N} / \mathrm{mm}^{2}$ 
2.3 Steps Involved In The Project

1. Modeling 2. Theoretical Calculation 3. Transient Thermal Analysis, Static Analysis And Dynamic Analysis For Piston And Also Transient Thermal Analysis For Piston Rings.

\section{Literature Survey}

3.1 Dynamics Of Internal Combustion Engine With Variable Compression Ratio: Internal combustion engines (ICE) with variable compression ratio (VCR) assures possibilities of exploitation characteristics and efficiency improvement, and reduces bad emissions and load of the elements of its crankshaft mechanism. The higher pressure and temperature of the operating substance at the end of the compression, as a result of higher compression ratio $-\varepsilon$, gives possibility for reduction of inductive period and increases the burning speed. We have a shorter time for combustion as a result of this, with lower loads and higher value of $\varepsilon$. It is also typical for ICE with VCR to have higher value of thermal efficiency. With the simulation model of the operating cycle of ICE with VCR were carried out numerical experiments at varying $\varepsilon$ to its various minimal values from 15 to 21 . The influence of change of $\varepsilon$ at constant intake pressure, equal to atmospheric $\mathrm{P}_{0}=101300 \mathrm{~Pa}$, was researched, both on the processes of operating cycle of ICE with VCR, and on the load of its mechanism units.

3.2 Steady State And Transient Analysis: This chapter discusses the details of literature survey of the piston structural and thermal analysis work done for assessing the integrity of the structure for various loading conditions like temperatures and pressures. This chapter also discusses the literature survey of experimental work done for measuring the above said work. Piston in the engine will be operating under vary critical temperature loads. These temperature loads will be varying from time to time in a cycle. These temperatures will be higher during firing stroke and lower during the other strokes. It is always difficult to assess the piston temperature for various gas temperatures. So steady state thermal analysis will be carried out for predicting the piston temperatures for worst case loading conditions i.e. peak temperatures or for an average bulk gas temperature.

4.1 Theoretical Equations

\section{Equations}

Ambient temperature $\left(\mathrm{T}_{1}\right)=35^{\circ} \mathrm{C}, \quad$ Atmospheric Pressure $\left(\mathrm{P}_{1}\right)=1.01325$ bar

Pressure of the end of compression $\left(\mathbf{P}_{2}\right)$ :

$\left.\frac{\mathrm{P}_{2}}{\mathrm{P}_{1}}=(\mathrm{r})\right)^{\gamma}, \quad \mathrm{r}=\left(\frac{\mathrm{V}_{2}}{\mathrm{~V}_{1}}\right)^{\gamma} \quad$ Where,

Pressure of the end of expansion $\left(\mathrm{P}_{4}\right)$ :

$\frac{\mathrm{P}_{3}}{\mathrm{P}_{4}}=\left(\frac{\mathrm{V}_{4}}{\mathrm{~V}_{3}}\right)^{\gamma}, \frac{\mathrm{P}_{3}}{\mathrm{P}_{4}}=(\mathrm{r})^{\gamma}, \mathrm{P}_{3}=$ Maximum pressure, $\mathrm{N} / \mathrm{mm}^{2}, \quad \mathrm{r}=$ Compression ratio, $\gamma=$ Adiabatic index

Temperature of the end of compression $\left(T_{2}\right)$ :

$\frac{\mathrm{T}_{2}}{\mathrm{~T}_{1}}=(\mathrm{r})^{\gamma^{-1}}$

Temperature of the beginning of expansion $\left(T_{3}\right)$ :

$\frac{\mathrm{T}_{3}}{\mathrm{~T}_{2}}=\frac{\mathrm{P}_{3}}{\mathrm{~K}} \quad \mathrm{~T}_{2}=$ Temperature at the end of compression, ${ }^{\circ} \mathrm{K} \quad \mathrm{T}_{3}=$ Temperature at the beginning of expansion ${ }^{\circ}$

Temperature of the end of expansion $\left(T_{4}\right)$ :

$\frac{T_{3}}{T_{4}}=(\mathrm{r})^{\gamma^{-1}}$

\section{Piston and piston ring Design}

Thickness of piston head based on the strength of piston material $\left(\mathrm{t}_{1}\right)=14 \mathrm{~mm}, \quad$ Thickness of rib $\left(\mathrm{t}_{2}\right)=6 \mathrm{~mm}$, Radial thickness of piston $\quad\left(\mathrm{t}_{3}\right)=3 \mathrm{~mm}, \quad$ Axial thickness of piston rings $\left(\mathrm{t}_{4}\right)=2.5 \mathrm{~mm}$, Radial depth of ring-groove $(b)=3.5 \mathrm{~mm}, \quad$ Thickness of barrel nearer to piston head $\left(\mathrm{t}_{5}\right) \quad=11 \mathrm{~mm}$, Thickness of barrel at the open end of the piston $\left(t_{6}\right)=3.5 \mathrm{~mm}$, Length of the skirt $\left(\mathrm{L}_{\mathrm{S}}\right)=78 \mathrm{~mm}$, Length of the ring section $\left(\mathrm{L}_{\mathrm{r}}\right)=17.5 \mathrm{~mm}, \quad$ Length of the piston $\left(\mathrm{L}_{\mathrm{p}}\right)=16 \mathrm{~mm}$ 


\subsection{MODELS OF PISTON AND PISTON RING DESIGN}

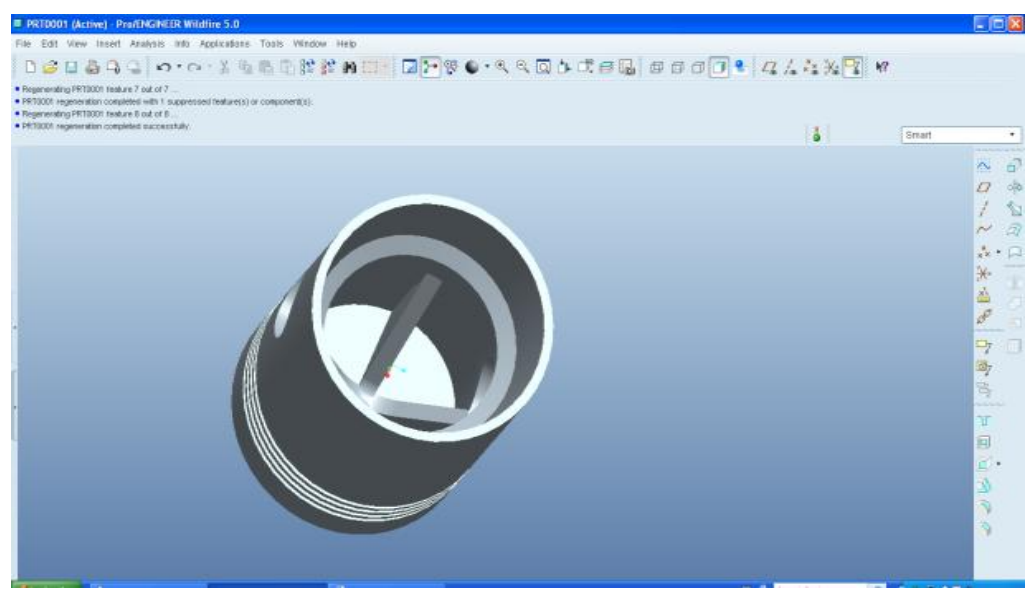

Figure 1: Piston

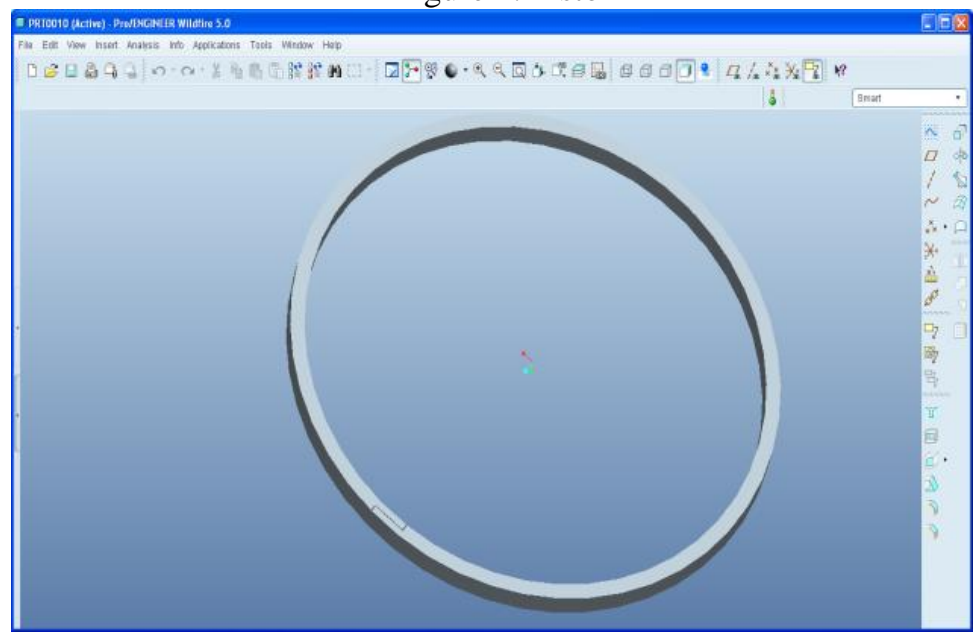

Figure 2: piston ring

5.2 MATERIAL PROPERTIES:

\begin{tabular}{|c|c|c|c|}
\hline \multirow[b]{2}{*}{ PROPERTY } & \multicolumn{3}{|c|}{ TYPE OF MATERIAL } \\
\hline & MILD STEEL & CAST IRON & $\begin{array}{l}\text { ALUMINUM ALLOY } \\
6061\end{array}$ \\
\hline YOUNG'S MODULUS(MPa) & 205000 & 103000 & 71000 \\
\hline POISSION'S RATIO & 0.29 & 0.211 & 0.34 \\
\hline DENISITY $\left(\mathrm{Kg} / \mathbf{m}^{3}\right)$ & 7850 & 7100 & 2650 \\
\hline $\begin{array}{l}\text { ULTIMATE TENSILE } \\
\text { STRENGTH(MPa) }\end{array}$ & 841 & 170 & 220 \\
\hline SPECIFIC HEAT $\left(\mathrm{J} / \mathrm{Kg}^{\circ} \mathrm{C}\right)$ & 475 & 460 & 897 \\
\hline $\begin{array}{l}\text { THERMAL } \\
\text { CONDUCTIVITY }\left(\mathrm{W} / \mathrm{mm}^{\circ} \mathrm{K}\right)\end{array}$ & 0.044 & 0.05 & 0.34 \\
\hline
\end{tabular}




\subsection{TRANSIENT THERMAL ANALYSIS OF PISTON}

\subsubsection{Compression Ratio 15:1}

Material Aluminium Alloy

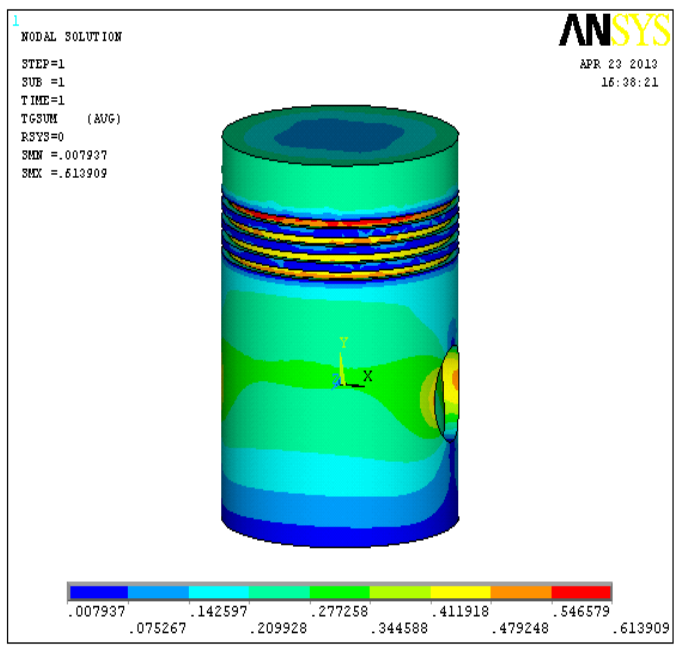

THERMAL GRADIENT

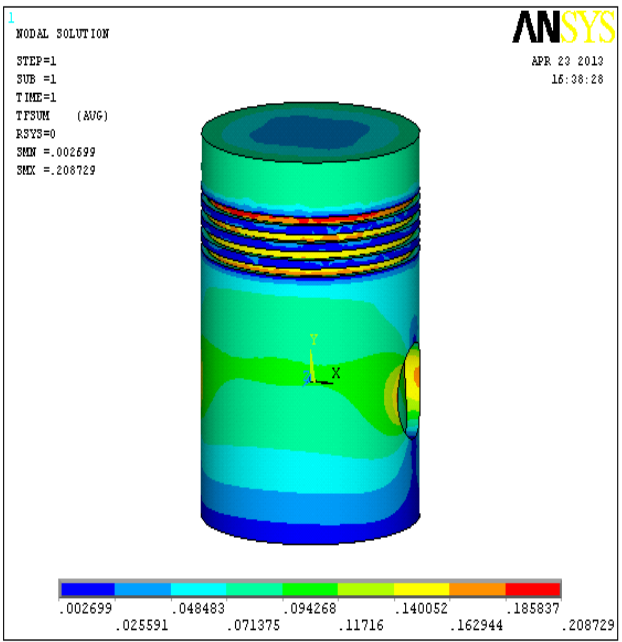

THERMAL FLUX

5.3.2 Compression ratio 15:1

Material cast iron

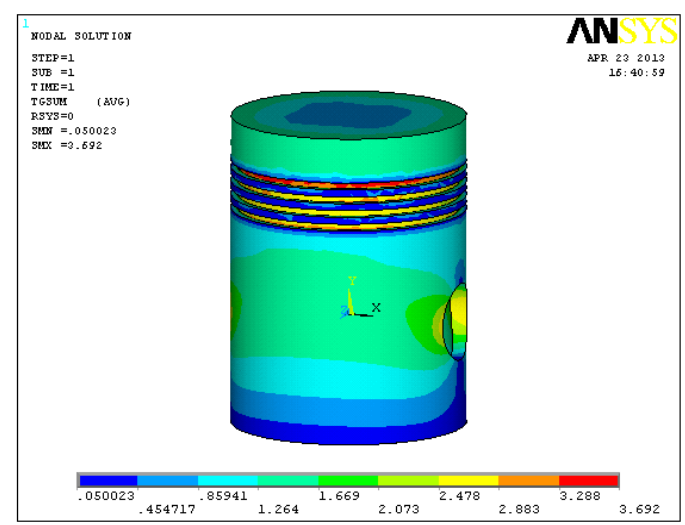

THERMAL GRADIENT

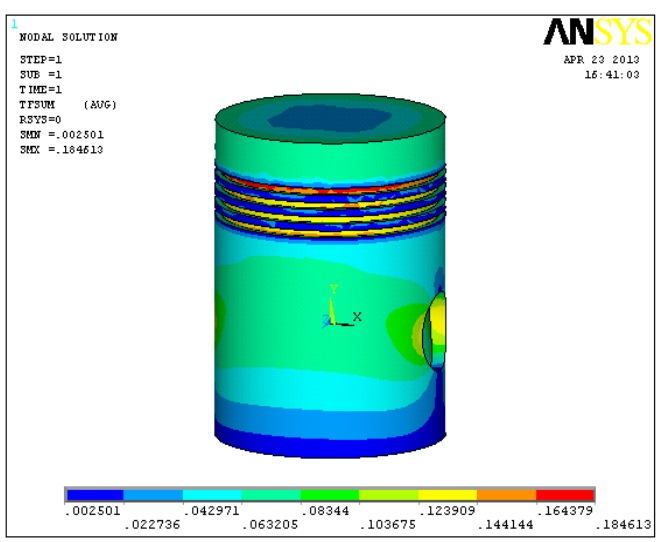

THERMAL FLUX

\subsection{DYNAMIC ANALYSIS OF PISTON}

5.4.1 Compression Ratio 20:1

Material Aluminum Alloy

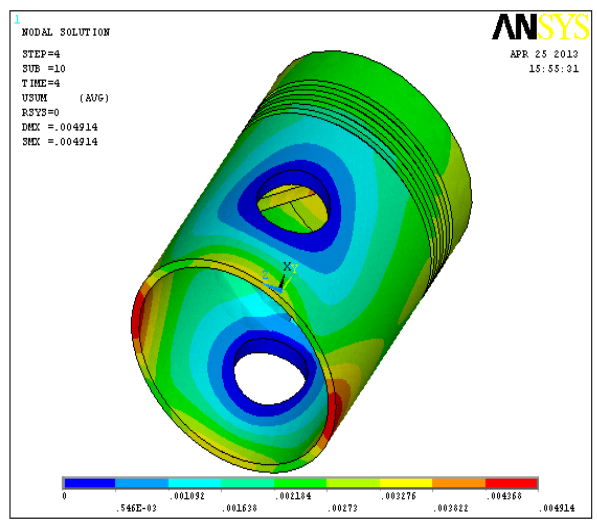

DISPLACEMENT

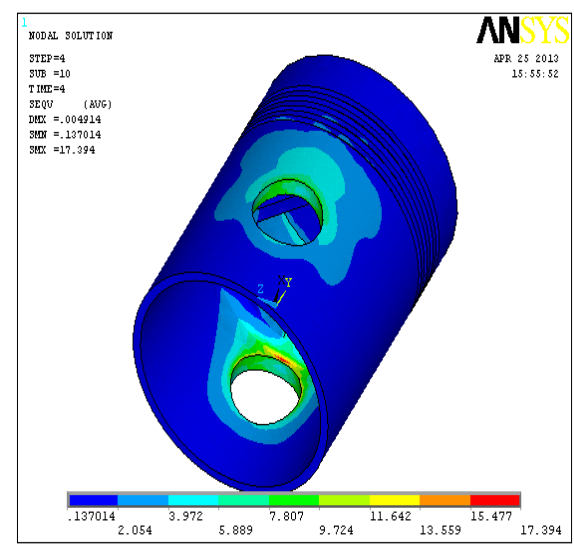

VON MISES STRESS 
5.4.2 Compression Ratio 20:1

Material Cast Iron

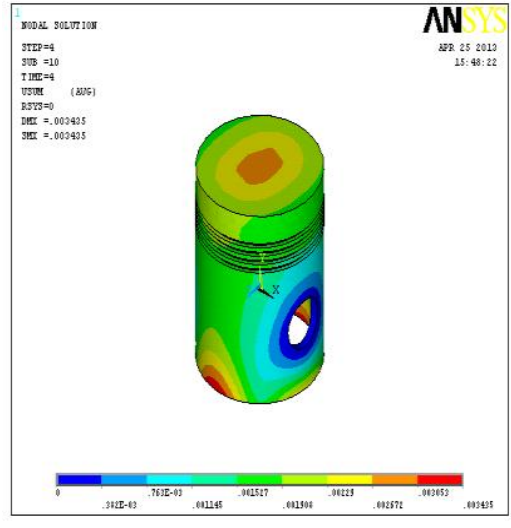

DISPLACEMENT

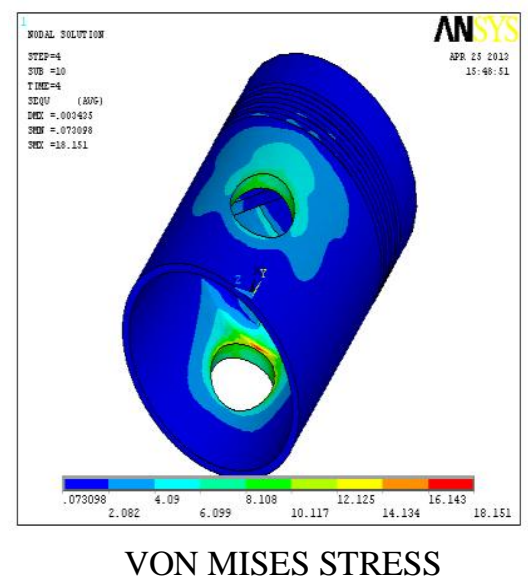

5.5 STATIC ANALYSIS OF PISTON

Material Aluminum Alloy
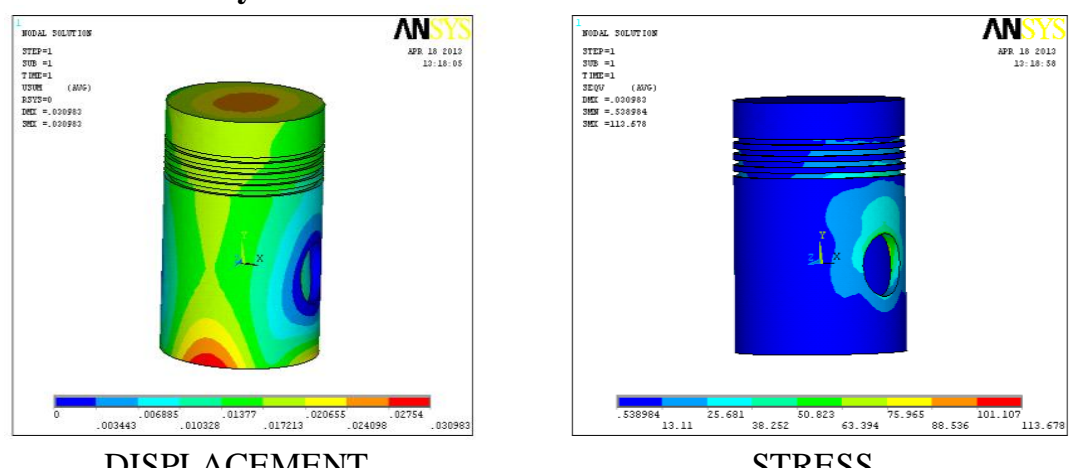

STRESS

Material cast iron
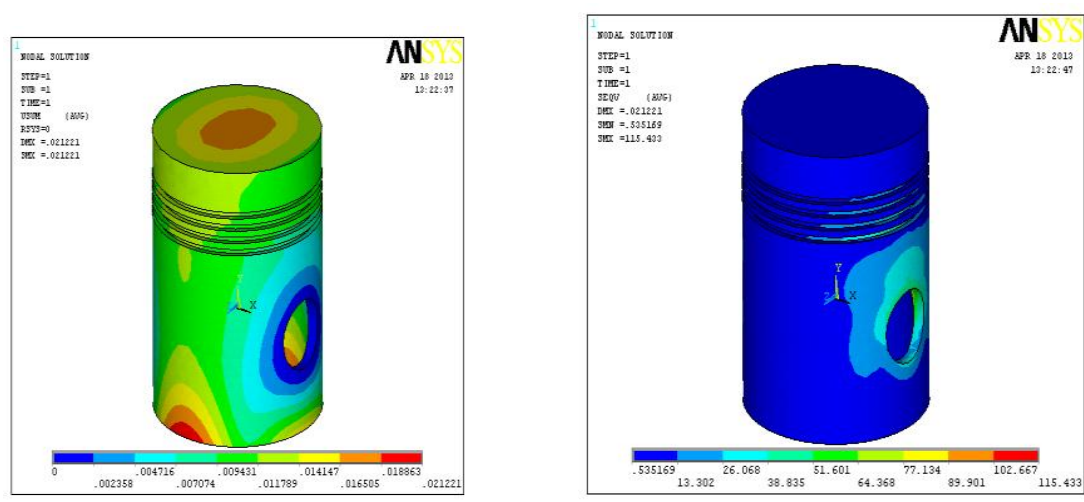
5.6 TRANSIENT THERMAL ANALYSIS OF PISTON RINGS

5.6.1 COMPRESSION RATIO 14:1

MATERIAL CAST IRON

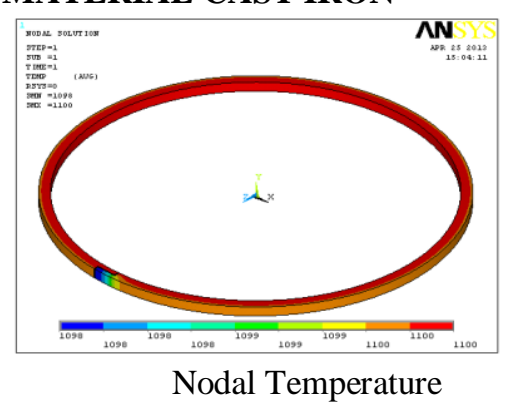

5.6.2 Compression Ratio 14:1

Material Mild Steel

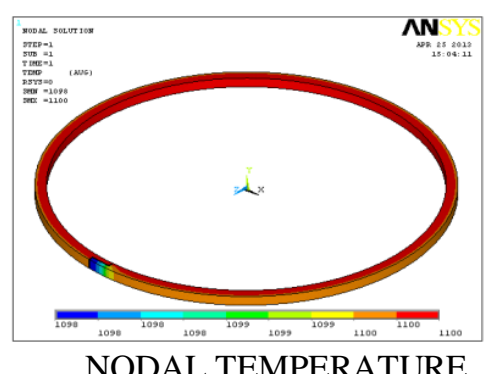

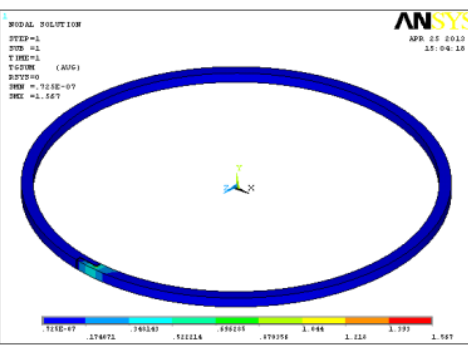

Thermal Gradient

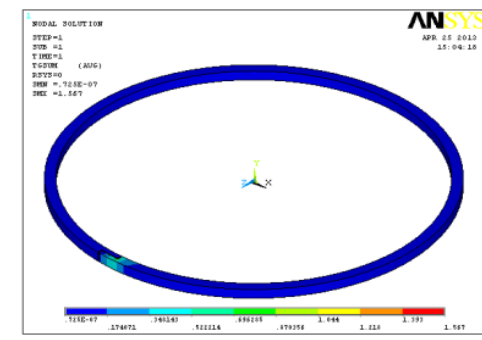

THERMAL GRADIENT

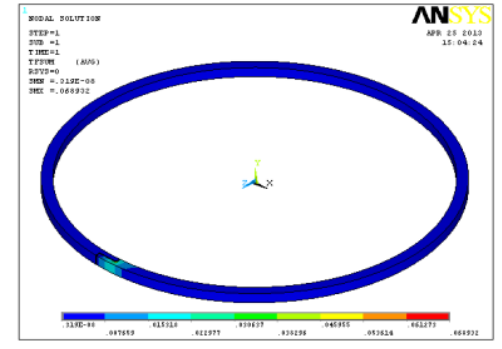

Thermal Flux

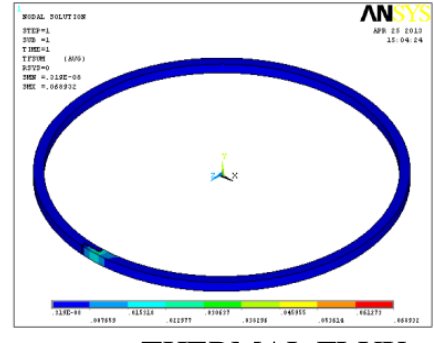

THERMAL FLUX

VI. Analysis Results Table

6.1 Transient Thermal Analysis Results Of Piston

Aluminum Alloy

\begin{tabular}{|l|l|l|l|l|l|}
\hline & \multicolumn{5}{l}{ COMPRESSION RATIOS } \\
\cline { 2 - 6 } & $\mathbf{1 4}$ & $\mathbf{1 5}$ & $\mathbf{1 8}$ & $\mathbf{2 0}$ & $\mathbf{2 5}$ \\
\hline $\begin{array}{l}\text { NODAL } \\
\text { TEMPERATURE } \\
\text { (K) }\end{array}$ & 1100 & 1027 & 855.67 & 770.14 & 616.05 \\
\hline $\begin{array}{l}\text { THERMAL } \\
\text { GRADIENT } \\
(\mathbf{K} / \mathbf{m m})\end{array}$ & 0.677001 & 0.613909 & 0.46678 & 0.393211 & 0.260669 \\
\hline $\begin{array}{l}\text { THERMAL FLUX } \\
\left(\mathbf{W} / \mathbf{m m}^{2}\right)\end{array}$ & 0.23018 & 0.208729 & 0.158705 & 0.133692 & 0.088628 \\
\hline
\end{tabular}

Cast Iron

\begin{tabular}{|c|c|c|c|c|c|}
\hline & \multicolumn{5}{|c|}{ COMPRESSION RATIOS } \\
\hline & 14 & 15 & 18 & 20 & 25 \\
\hline $\begin{array}{l}\text { NODAL } \\
\text { TEMPERATURE }\end{array}$ & 1100 & 1027 & 855.67 & 770.14 & 616.05 \\
\hline $\begin{array}{l}\text { THERMAL } \\
\text { GRADIENT }\end{array}$ & 4.072 & 3.692 & 2.807 & 2.365 & 1.568 \\
\hline THERMAL FLUX & 0.203586 & 0.184613 & 0.140369 & 0.118245 & 0.078388 \\
\hline
\end{tabular}

6.2 Dynamic Analysis Results Of Piston

Aluminum Alloy

\begin{tabular}{|l|l|l|l|l|l|}
\hline & $\mathbf{1 4}$ & $\mathbf{1 5}$ & $\mathbf{1 8}$ & $\mathbf{2 0}$ & $\mathbf{2 5}$ \\
\hline DISPLACEMENT & $0.959 \mathrm{E}-3$ & $0.894 \mathrm{E}-3$ & 0.005671 & 0.0049414 & 0.057129 \\
\hline $\begin{array}{l}\text { VON MISES } \\
\text { STRESS }\end{array}$ & 3.159 & 2.913 & 20.156 & 17.394 & 205.646 \\
\hline $\begin{array}{l}\text { VON MISES } \\
\text { TOTAL STRAIN }\end{array}$ & $0.450 \mathrm{E}-4$ & $0.415 \mathrm{E}-4$ & $0.287 \mathrm{E}-3$ & $0.248 \mathrm{E}-3$ & 0.00293 \\
\hline
\end{tabular}




\begin{tabular}{|l|l|l|l|l|l|}
\hline \multicolumn{1}{|c|}{ Cast Iron } \\
\hline DISPLACEMENT & $\mathbf{1 4}$ & $\mathbf{1 5}$ & $\mathbf{1 8}$ & $\mathbf{2 0}$ & $\mathbf{2 5}$ \\
\hline VON MISES STRESS & 3.464 & 3.417 & 20.986 & 0.003435 & 0.03894 \\
\hline $\begin{array}{l}\text { VON MISES TOTAL } \\
\text { STRAIN }\end{array}$ & $0.341 \mathrm{E}-4$ & $0.317 \mathrm{E}-4$ & $0.207 \mathrm{E}-3$ & $0.179 \mathrm{E}-3$ & 0.002078 \\
\hline
\end{tabular}

\subsection{Static Analysis Results Of Piston}

\begin{tabular}{|l|l|l|l|}
\hline & DISPLACEMENT $(\mathbf{m m})$ & STRESS $\left(\mathbf{N} / \mathbf{m m}^{2}\right)$ & STRAIN \\
\hline ALUMINUM ALLOY & 0.030983 & 113.678 & 0.002287 \\
\hline CAST IRON & 0.021221 & 115.433 & 0.001135 \\
\hline
\end{tabular}

\subsection{Transient Thermal Analysis Results Of Piston Ring} Mild Steel

\begin{tabular}{|l|l|l|l|l|l|}
\hline & \multicolumn{5}{|l}{ COMPRESSION RATIOS } \\
\cline { 2 - 6 } & $\mathbf{1 4}$ & $\mathbf{1 5}$ & $\mathbf{1 8}$ & $\mathbf{2 0}$ & $\mathbf{2 5}$ \\
\hline \multirow{2}{*}{ NODAL TEMPERATURE } & 1100 & 1027 & 855.67 & 770.14 & 616.05 \\
\hline THERMAL GRADIENT & 1.567 & 1.419 & 1.074 & 0.901474 & 0.590815 \\
\hline THERMAL FLUX & 0.068932 & 0.062425 & 0.047252 & 0.039665 & 0.025996 \\
\hline
\end{tabular}

\section{Cast Iron}

\begin{tabular}{|c|c|c|c|c|c|}
\hline & \multicolumn{5}{|c|}{ COMPRESSION RATIOS } \\
\hline & 14 & 15 & 18 & 20 & 25 \\
\hline $\begin{array}{l}\text { NODAL } \\
\text { TEMPERATURE }\end{array}$ & 1100 & 1027 & 855.67 & 770.14 & 616.05 \\
\hline THERMAL GRADIENT & 1.379 & 1.249 & 0.945319 & 0.793531 & 0.52007 \\
\hline THERMAL FLUX & 0.068953 & 0.062444 & 0.047266 & 0.039677 & 0.026004 \\
\hline
\end{tabular}

\section{Conclusion}

In this we have designed a piston and piston rings for multi cylinder petrol engine Toyota Car 86 theoretically and modeled in 3D modeling software Pro/Engineer. Present used compression ratio is 10:1. In this thesis, we are calculating temperatures developed in the multi cylinder petrol engine by varying compression ratios 14:1, 15:1, 18:1, 20:1 and 25:1 by mathematical correlations. And also we have calculated pressure developed by varying the compression ratios. We have transient thermal analysis on the piston by applying the temperatures calculated for all compression ratios using two materials Aluminum alloy 6061 and Cast Iron. We have also done dynamic analysis on the piston by applying pressures calculated. And also static analysis by applying the maximum pressure.

By observing the transient thermal analysis results, using compression ratio 15:1 is better since its heat transfer rate is more due to its high thermal flux value. By observing the dynamic analysis results, the analyzed stress values are less than their respective yield stress values for both Aluminum alloy 6061 and Cast Iron for all compression ratios. But by using compression ratio $25: 1$ is not preferable because the stress value is very high compared with that of other compression ratios. So we can conclude that using compression ratio 20:1 is better if we consider thermal and also dynamic results. And also using Aluminum alloy 6061 for piston is better than Cast Iron due to its high thermal flux values. We have also done transient thermal analysis on the piston ring. By observing the analysis results using material Cast Iron and Compression ratio 14:1 is better.

\subsection{Future Scope}

From this thesis, we have concluded that using compression ratios 15:1 and 20:1 is better analytically, but practically 10:1 is used. So practical experiments have to be done to validate the use of compression ratios 15:1 or 20:1 in IC engines.

\section{References}

[1]. A Text Book of Internal Combustion Engines: by Rajput, Laxmi publications.

[2]. A Text Book of Thermal Engineering by R.K. Rajput, Laxmi publications.

[3]. A Text Book of Internal combustion engine fundamentals by John B. Heywood, TATA McGraw Hill.

[4]. A Text Book of Automobile Engineering by R.K. Rajput, Laxmi publications.

[5]. A Text Book of Internal Combustion Engines 3e by V. Ganesan, TATA McGraw Hill.

[6]. A Text Book of Fundamentals Of Internal Combustion Engines by H.N. Gupta, PHI publishers.

[7]. A Text Book of Internal Combustion Engines by Shyam K. Agrawal, TATA McGraw Hill.

[8]. A Text Book of Automotive Engines by S Srinivasan, TATA McGraw Hill.

[9]. 10. A Text Book of Design data Hand book by S.Md.Jalaludeen, Anuradha Publications. 